\title{
Antibacterial activity of ethanolic extract of Acalypha wilkesiana leaves growing in Jos, Plateau State, Nigeria
}

\author{
Gotep, J. G., ${ }^{1 \star}$ Agada, G. O. A., ${ }^{2}$ Gbise, D. S. ${ }^{3}$ and Chollom, S. ${ }^{4}$ \\ 1'Biochemistry and Applied Molecular Biology Division, National Veterinary Research Institute Vom, Plateau State, \\ Nigeria. \\ ${ }^{2}$ Microbiology Section Central Diagnostic Division, National Veterinary Research Institute Vom, Plateau State, Nigeria. \\ ${ }^{3}$ Parasitology Division, National Veterinary Research Institute Vom, Plateau State, Nigeria. \\ ${ }^{4}$ Virology Division, National Veterinary Research Institute Vom, Plateau State, Nigeria. \\ E-mail:jurbe4u@yahoo.com
}

Received 21 September 2009; received in revised form 27 October 2009; accepted 31 October 2009

\begin{abstract}
Antibacterial activity of ethanolic extract of Acalypha wilkesiana leaves growing in Vom, Jos, Plateau state, Nigeria was carried out to verify claims by the locals of its medicinal properties. We tested the extract for activity against Staphylococcus aureus (G+), Yersinia enterocolitica, Escherichia coli, Salmonella typhi, Pseudomonas aeruginosa and Klebsiella aerogenes (G-). The extract exhibited activity against the organisms in varying degrees. In the agar diffusion test, $Y$. enterocolitica showed the highest zone of inhibition $(18 \mathrm{~mm})$ at the highest concentration of extract tested $(20$ $\mathrm{mg} / \mathrm{mL}$ ) while E. coli, S. aureus, S. typhi, P. aeruginosa and $K$. aerogenes showed zones of inhibition of 17, 16, 15, 14 and $16 \mathrm{~mm}$ respectively. At extract concentration of $2.5 \mathrm{mg} / \mathrm{mL}, Y$. enterocolitica and $P$. aeruginosa did not show any zones of inhibition while E.coli, S. aureus, S. typhi, and K. aerogenes showed zones of inhibition of 7, 6, 6 and $7 \mathrm{~mm}$ respectively. Below extract concentration of $2.5 \mathrm{mg} / \mathrm{mL}$, there was no zone of inhibition observed with any organism. The MIC of the extract against the organisms was $5 \mathrm{mg} / \mathrm{mL}$ except on $S$. aureus where the MIC was $2.5 \mathrm{mg} / \mathrm{mL}$. The MBC of the extract was $10 \mathrm{mg} / \mathrm{mL}$ against $Y$. enterocolitica, S. typhi, $P$. aeruginosa and $K$. aerogenes, $5 \mathrm{mg} / \mathrm{mL}$ against $E$. coli and $S$. aureus. Preliminary phytochemical testing revealed the presence of tannins, steroids, flavonoids and cardiac glycosides while saponins, alkaloids and anthraquinones were not present. The result gives scientific backing to the use of the leaves by the local people in the treatment of conditions usually associated with the organisms tested.
\end{abstract}

Keywords: Acalypha wilkesiana, ethanolic extract, antibacterial activity, Jos Plateau State

\section{INTRODUCTION}

Since the discovery of the first antibiotic, penicillin, the need for antimicrobial agents is yet to be satisfied. This has been attributed to the emergence of antibiotic resistant strains of micro organisms (Davies, 1994). As a result, there is a continuous search for antimicrobials from plant sources. These plants are used either alone or in combination with known antibiotics for treating bacterial infections (Collin and Pareicia, 1970).

During the last two decades, there has been a considerable increase in the study and use of medicinal plants all over the world especially in advanced countries. There was also increase in the international commerce and commercial exploitation of herbal medicines through over the counter labeled products. In some countries, herbal medicines are still a central part of the medical system e.g. China (Liu, 1987), Ethiopia (Desta, 1993), Argentina (Anesini and Perez, 1993) and Papua New Guinea (Nick et al., 1995). The renewed interest in the use of medicinal plants may be attributed to cheapness, availability, and accessibility by the local populace, high incidence of side effects of synthetic medicines and environmental friendliness of plant extracts.

Medicinal plants also serve as the starting point for the discovery of semi synthetic chemical compounds. The chemical structures derived from plant substances can also be used as models for new synthetic compounds (Sofowora, 1989; Akerele, 1992). Medicinal plants have been used in Africa before the introduction of antibiotics and other modern drugs (Kabir et al., 2005).

About $80 \%$ of the populations in developing countries still use traditional medicine for their healthcare. Modern pharmacopoeias contain at least $25 \%$ of drugs derived from plants and many others which are synthetic analogues build on prototype compounds isolated from plants (De Silva, 2005). Phytochemical research based on ethno pharmacological information is generally considered an effective approach in the discovery of new antiinfective agents from higher plants (Kloucek et al., 2005).

The genus "Acalypha" comprises about 570 species (Riley, 1963). A. wilkesiana belongs to the Euphobiaceae family. The plant is popularly used for the treatment of malaria, dermatological disorders, gastrointestinal disorders (Akinde and Odeyemi, 1987) and for its 
antimicrobial property (Adesina et al., 1980; 2000; Kabir et al., 2005, Oladunmoye, 2006; Erute and Oyibo, 2008). It is widely used in southern Nigeria as a remedy for the treatment of undefined skin infections in children (Alade and Irobi, 1992).

Antimicrobial screening has been carried out on the leaves of $A$. wilkesiana. Adesina and coworkers (2000) reported a seasonal variation in the distribution of the three natural antimicrobial phenols (geraniin, corilagin and gallic acid) in the genus Acalypha. Previous antimicrobia screening of the leaves of $A$. wilkesiana were carried out using plants growing in south western part of Nigeria. This study was done using $A$. wilkesiana plants growing in Jos town in north central Nigeria which has different climatic conditions from south western Nigeria and some bacteria which had hitherto not been tested in those previous studies were also tested.

\section{MATERIALS AND METHODS}

\section{Plant preparation and extraction}

Pesticide free leaves of $A$. wilkesiana were collected from National Veterinary Research Institute Vom. The plant was identified at the Federal College of Forestry Jos. The leaves were washed with distilled water and dried in the oven at $40{ }^{\circ} \mathrm{C}$. The dried leaves were pulverized using pestle and mortar in the laboratory. Extraction was done using the soxhlet apparatus. Briefly, $40 \mathrm{~g}$ of the powdered leaves was wrapped in a filter paper and placed in a soxhlet and extracted with absolute ethanol. The extraction was done until the solvent in the soxhlet turned colourless. The extract was concentrated by recovering the solvent using the soxhlet apparatus until the extract became just pourable. It was poured into a pre weighed beaker and placed in the oven at $40^{\circ} \mathrm{C}$ to dry.

\section{Phytochemical testing}

Testing for the presence of phytochemicals was carried out using the methods in Trease and Evans (1989).

\section{Test for alkaloids}

About $0.5 \mathrm{~g}$ of extract was stirred with $3 \mathrm{~mL}$ of $1 \%$ aqueous hydrochloric acid on a steam bath and filtered; 1 $\mathrm{mL}$ of the filtrate was treated with few drops of the following reagents:

1. Mayer's reagent

2. Picric acid solution

3. Dragendorff's reagent

Precipitation with either of these reagents was taken as preliminary evidence for the presence of alkaloids.

\section{Test for saponins}

About $0.5 \mathrm{~g}$ of the extract was shaken with water in a test tube. Frothing which persists on warming was taken as a preliminary evidence for presence of saponins.

\section{Test for tannins}

About $0.5 \mathrm{~g}$ of the extract was stirred with $1 \mathrm{~mL}$ of distilled water and filtered. Ferric chloride solution was added to the filtrate. A blue-black, green or blue-green precipitate was taken as evidence for the presence of tannins.

\section{Test for anthraquinones}

A $0.5 \mathrm{~g}$ of extract was taken into a dry test tube and $5 \mathrm{~mL}$ of chloroform was added and shaken for 5 minutes. It was filtered and the filtrate shaken with equal volume of $100 \%$ ammonia solution. Pink, violet or red color in the ammoniacal layer (lower layer) indicates the presence of free anthraquinones.

\section{Test for cardiac glycosides (Keller Killiani test)}

A $0.1 \mathrm{~g}$ of extract was dissolved in $1 \mathrm{~mL}$ of glacial acetic acid containing one drop of ferric chloride solution. A $1 \mathrm{~mL}$ of concentrated sulphuric acid was added gently by the side of the test tube. A brown ring obtained at the interphase indicates the presence of deoxy sugar characteristic of cardenolides.

\section{Test for steroids (Steroidal ring)}

About $0.1 \mathrm{~g}$ of the extract was dissolved in $2 \mathrm{~mL}$ of chloroform; sulphuric acid was carefully added to form a lower layer. A reddish brown color at the interphase is indicative of the presence of steroidal ring.

\section{Test for flavonoids}

A $2 \mathrm{~g}$ of powdered sample was detanned with acetone. The sample was placed on a hot water bath for all traces of acetone to evaporate. Boiling distilled water was added to the detanned sample. The mixture was filtered while hot. The filtrate was cooled and $5 \mathrm{~mL}$ of $20 \%$ sodium hydroxide was added to equal volume of the filtrate. A yellow solution indicates the presence of flavonoids.

\section{Preparation of various concentrations of extract}

The extract was reconstituted in distilled water to obtain various concentrations of the extract thus: $2 \mathrm{~g}$ of extract was reconstituted in distilled water to obtain $100 \mathrm{~mL}$ of a $20 \mathrm{mg} / \mathrm{mL}$ solution. A portion of the $20 \mathrm{mg} / \mathrm{mL}$ solution was diluted with an equal volume of distilled water to obtain a $10 \mathrm{mg} / \mathrm{mL}$ solution. The double dilution procedure was continued to obtain lower concentrations of the extract.

\section{Test organisms}

The test organisms were clinical isolates from Department of Bacteriology, Federal College of Veterinary and Medical Laboratory Technology Vom, Plateau State. The following organisms were used: Y. enterocolitica, E. coli, S. aureus, $S$. typhi, $P$. aeruginosa and $K$. aerogenes. 


\section{Preparation of the test organisms}

The isolates were sub-cultured onto selective and differential solid media and re-identified using biochemical tests.

\section{Standardization of inoculum}

Five colonies of each organism were inoculated into nutrient broth (NB) and incubated at $37^{\circ} \mathrm{C}$ for 18 to $24 \mathrm{~h}$. Turbidity produced was adjusted to match $0.5 \mathrm{Mc}$ Farland standard about $10^{8} \mathrm{cfu} / \mathrm{mL}$. It was further adjusted to $10^{5}$ $\mathrm{cfu} / \mathrm{mL}$.

\section{Bacterial susceptibility testing}

\section{Agar Diffusion test}

Sterile nutrient agar (NA) plates were prepared and $24 \mathrm{~h}$ old standardized cultures of bacteria were separately used to flood the nutrient agar surfaces of each plate and excess was drained off. A sterile cork borer of $5 \mathrm{~mm}$ diameter was used to make six ditches on each plate. 0.1 $\mathrm{mL}$ of reconstituted extract equivalent to $2 \mathrm{mg}$ of the extract was dropped into each approximate labeled ditch and into the remaining two ditches gentamicin $(40 \mathrm{mg} / \mathrm{mL})$ and distilled water were used as positive and negative controls respectively. The inoculated plates were left on the table for $1 \mathrm{~h}$ to allow the extract to diffuse into the agar. The NA plates were incubated aerobically at $37^{\circ} \mathrm{C}$ for 24 $\mathrm{h}$ and $Y$. enterocolitica at $30{ }^{\circ} \mathrm{C}$ for $24 \mathrm{~h}$. Zones of inhibition produced after incubation were measured in millimeters (Abayomi, 1982; Okwori et al., 2007).

Determination of MIC (minimum inhibitory concentration) and $M B C$ (minimum bactericidal concentration)

MIC was determined by the tube dilution method. (Baron and Fingold, 1990). The MIC was taken as the least concentration that inhibited the growth of the test organisms. MBC was determined by sub-culturing the test dilutions onto fresh solid medium and incubated further for 18 to $24 \mathrm{~h}$. The highest dilution that yielded no single bacterial colony on a solid medium was taken as the MBC.

\section{RESULTS}

The percentage yield of the extract was $10.16 \%$. The phytochemical testing of the extract gave positive reactions for tannins, flavonoids, steroids and cardiac glycosides and negative reactions for saponins, alkaloids and anthraquinones as shown on Table 1.

The extract inhibited the growth of all the organisms tested in varying degrees at various concentrations as indicated by their zones of inhibition in Table 2. $Y$. enterocolitica showed zone of inhibition of $(18 \mathrm{~mm})$ at the highest concentration of extract tested $(20 \mathrm{mg} / \mathrm{mL})$ while $E$. coli, S. aureus, S. typhi, $P$. aeruginosa and $K$. aerogenes showed zones of inhibition of 17, 16, 15, 14 and $16 \mathrm{~mm}$ respectively. At extract concentration of $2.5 \mathrm{mg} / \mathrm{mL}$, no zone of inhibition was observed with $Y$. enterocolitica and

Table 1: Qualitative Phytochemical analysis of Ethanolic extract of Acalypha wilkesiana leaves

\begin{tabular}{ll}
\hline Phytochemical & Result \\
\hline Tannins & Present \\
Flavonoids & Present \\
Steroids & Present \\
Cardiac Glycosides & Present \\
Saponins & Not present \\
Alkaloids & Not present \\
Anthraquinones & Not present \\
\hline
\end{tabular}

Table 2: Antibacterial activity of Ethanolic extract of Acalypha wilkesiana leaves showing zones of inhibition at different concentrations of the extract

\begin{tabular}{|c|c|c|c|c|c|c|c|}
\hline Isolates & \multicolumn{7}{|c|}{ Mean zone of inhibition diameter (mm) } \\
\hline Yersinia enterocolitica & 18 & 11 & 7 & 0 & 0 & 20 & 0 \\
\hline Escherichia coli & 17 & 12 & 10 & 7 & 0 & 22 & 0 \\
\hline Staphylococcus aureus & 16 & 12 & 9 & 6 & 0 & 18 & 0 \\
\hline Salmonella typhi & 15 & 12 & 7 & 6 & 0 & 21 & 0 \\
\hline Pseudomonas aeruginosa & 14 & 11 & 6 & 0 & 0 & 17 & 0 \\
\hline Klebsiella aerogenes & 16 & 10 & 9 & 7 & 0 & 21 & 0 \\
\hline Concentration of extract $(\mathrm{mg} / \mathrm{mL})$ & 20 & 10 & 5 & 2.5 & 1.25 & $+\mathrm{C}$ & $-\mathrm{C}$ \\
\hline
\end{tabular}

$+\mathrm{C}=$ Gentamicin $40 \mathrm{mg} / \mathrm{mL}$

$-\mathrm{C}=$ Sterile distilled water 
Table 3: Minimum inhibitory concentrations $(\mathrm{mg} / \mathrm{mL})$ of Ethanolic extract of Acalypha wilkesiana leaves

\begin{tabular}{|c|c|c|c|c|c|c|c|c|c|}
\hline \multirow[t]{2}{*}{ Isolates } & \multicolumn{9}{|c|}{ Concentration of extract $(\mathrm{mg} / \mathrm{mL})$} \\
\hline & 20 & 10 & 5 & 2.5 & 1.25 & 0.625 & 0.313 & 0.156 & 0.078 \\
\hline Yersinia enterocolitica & - & - & - & + & + & + & + & + & + \\
\hline Escherichia coli & - & - & - & + & + & + & + & + & + \\
\hline Staphylococcus aureus & - & - & - & - & + & + & + & + & + \\
\hline Salmonella typhi & - & - & - & + & + & + & + & + & + \\
\hline Pseudomonas aeruginosa & - & - & - & + & + & + & + & + & + \\
\hline Klebsiella aerogenes & - & - & - & + & + & + & + & + & + \\
\hline
\end{tabular}

- = No growth

$+=$ Growth

Table 4: Minimum Bactericidal Concentration ( $\mathrm{mg} / \mathrm{mL}$ ) of Ethanolic extract of Acalypha wilkesiana leaves

\begin{tabular}{|c|c|c|c|c|c|c|c|c|c|}
\hline \multirow[t]{2}{*}{ Isolates } & \multicolumn{9}{|c|}{ Concentration of extract (mg/mL) } \\
\hline & 20 & 10 & 5 & 2.5 & 1.25 & 0.625 & 0.313 & 0.156 & 0.078 \\
\hline Yersinia enterocolitica & - & - & + & + & + & + & + & + & + \\
\hline Escherichia coli & - & - & - & + & + & + & + & + & + \\
\hline Staphylococcus aureus & - & - & - & + & + & + & + & + & + \\
\hline Salmonella typhi & - & - & + & + & + & + & + & + & + \\
\hline Pseudomonas aeruginosa & - & - & + & + & + & + & + & + & + \\
\hline Klebsiella aerogenes & - & - & + & + & + & + & + & + & + \\
\hline
\end{tabular}

- = No growth

$+=$ Growth

$P$. aeruginosa while E. coli, S. aureus, S. typhi and $K$. aerogenes showed zones of inhibition of 7,6,6 and $7 \mathrm{~mm}$ respectively at that concentration $(2.5 \mathrm{mg} / \mathrm{mL})$. The positive control gentamicin had average zone of inhibition of $21 \mathrm{~mm}$. The negative control did not show any zone of inhibition.

The lowest MIC was observed with $S$. aureus at a concentration of $2.5 \mathrm{mg} / \mathrm{mL}$. Other organisms tested showed MIC at $5.0 \mathrm{mg} / \mathrm{mL}$ concentration as shown on Table 3.

The MBC of the extract for all the organisms tested were slightly higher than the MIC except for E. coli where MIC and MBC were the same. For $Y$. enterocolitica, $S$. typhi, $P$. aeruginosa, and $K$. aerogenes the MBC was 10.0 $\mathrm{mg} / \mathrm{mL}$ of extract while for $E$. coli and $S$. aureus, the MBC was $5 \mathrm{mg} / \mathrm{mL}$ as shown on Table 4.

\section{DISCUSSION}

Phytochemical research based on ethnopharmacological informations is generally considered an effective approach to the discovery of antinfective agents from higher plants (Kloucek et al., 2005).

The presence of zones of inhibition on the seeded agar plates showed that the plant extract possesses antibacterial activity on the tested organisms which included both Gram positive and Gram negative organisms. Although the zones of inhibition were lower than that exhibited by the standard drug gentamicin, this could be due to the fact that the plant extract is crude and contains other constituents that do not possess antibacterial property. Also the ability of the extract to diffuse through the gel may be hindered because of large molecules (stearic hindrance). At higher concentrations of the extract, the zones of inhibition with the standard drug were comparable.

$Y$. enterocolitica showed the highest zone of inhibition at the highest concentration of extract tested $(20 \mathrm{mg} / \mathrm{mL})$ but showed no zone of inhibition at lower concentrations where other organisms ( $E$. coli, $S$. aureus, S. typhi and $K$. aerogenes) showed zones of inhibition. This suggests that higher concentration of the extract is needed to inhibit the growth of $Y$. enterocolitica but once that threshold is attained, it becomes very sensitive.

S. aureus had the lowest MIC $(2.5 \mathrm{mg} / \mathrm{mL})$. This shows that the organism is more sensitive to the extract than other organisms tested. This gives credence to its traditional use for the treatment of boils and wounds. All organisms tested except E. coli had higher MBC than MIC. This shows that higher concentrations of extract was needed to kill the bacteria than that required to inhibit their growth. For E. coli the concentration that inhibited growth of the organism was sufficient to kill the organism. This may make it a good bactericidal agent against $E$. coli.

Generally, the antibacterial activity of the extract against $E$. coli, $S$. aureus, and $P$. aeruginosa agrees with earlier works by Akinde and Odebiyi (1987), Adesina et al. (1980), Kabir et al. (2005) and Oladunmoye (2006). In addition the ethanolic extract of $A$. wilkesiana had antibacterial activity against $Y$. enterocolitica, S. typhi and $K$. aerogenes which had hitherto not been tested. Phytochemical testing of the extract showed that the extract contains cardiac glycosides, flavonoids, steroids and tannins while saponins, alkaloids, anthraquinones and terpenes were absent. This result differs slightly from Oladunmoye (2006) who reported the presence of saponins in the extract. This could be attributed to the different locations where the plants were collected: Jos in 
North Central Nigeria located at Lat. 9 ${ }^{\circ} 56^{\prime} \mathrm{N}$ and Long. $8^{\circ} 53^{\prime} \mathrm{E}, 1,217 \mathrm{~m}$ above sea level and enjoys a more temperate climate than much of the rest of Nigeria and Akure located at Lat. $7^{\circ} 15^{\prime} \mathrm{N}$ and Long. 5 $11^{\prime} \mathrm{E} 385 \mathrm{~m}$ above sea level with a more tropical climate. There is relationship between chemical composition of plants and geographical location. Rao and Rout reported a variation in the composition of essential oils of Jasminum sambac. (L.) collected from different parts of India (Rao and Rout, 2003). The composition of bee propolis has also been found to depend on geographical source (Evans, 2005). It contains flavonoids and phenolic esters in temperate regions but these compounds are absent in propolis obtained from tropical regions although both exert antibacterial property. Seasonal changes in the antimicrobial constituents of $A$. wilkesiana have also been reported. The report also attributed the antimicrobial property of the extract to its tannins: geraniin, corilagin and gallic acid (Adesina et al., 2000).

\section{CONCLUSIONS}

Ethanolic extract of $A$. wilkesiana leaves growing in Jos Plateau State Nigeria had antibacterial activity on some bacterial organisms tested to varying degrees. This supports the traditional use of the leaves for treatment of ailments associated with these bacteria. Research should be carried out on the toxicity of the plant in order to know the safety and toxicity of the plant and establish a safe dosage regimen since the infusion of the leaves is taken orally by local people for treating gastrointestinal disturbances and as an enema for children apart from its topical use for treating dermatological disorders.

\section{ACKNOWLEDGEMENT}

We want to acknowledge Dr. Joshua Kamani of Parasitology Division National Veterinary Research Institute Vom, for reading through the manuscript and making useful suggestions.

\section{REFERENCES}

Alade, P. J. and Irobi, O. N. (1992). Anti-microbial activities of crude leaf extracts of Acalypha wilkesiana. Journal of Ethnopharmacology 39, 171174.

Abayomi, S. (1982). The State of Medicinal Plants Research in Nigeria. University of Ife Press, Nigeria. pp. 200.

Adesina S. K., Idowu O., Ogundaini, A. O., Oladimeji, H., Olubgade T. A., Onawunmi, G. O., and Pais, M. (2000). Antimicrobial constituents of the leaves of Acalypha wilkesiana and Acalypha Hispida. Phytotherapy Research 14, 371-374.

Adesina, S. K., Oguntimehin, B. J. and Akinwusi, D. D. (1980). Phytochemical and biological examination of the leaves of Acalypha wilkesiana Muell. Arg Quarterly. Journal of Crude Drug Research 18, 45-48.
Akerele, O. (1992). WHO guidelines for the assessment of herbal medicines: Fitoterapia 60, 99-110.

Akinde, B. E. and Odeyemi, O. O. (1987). Extraction and microbiological evaluation of the oils from leaves of Acalypha wilkesiana. Nigerian Medical Journal 17, 163-165.

Anesini, C. and Perez, C. (1993). Screening of plants used in Argentine folk medicine for antimicrobial activity. Journal of Ethnopharmacology 39, 119-128.

Baron, J. E. and Fingold, S. M. (1990). Methods for testing antimicrobial effectiveness. In: Bailey Scotts Diagnostic Microbiology. Mosby, C. V. (ed), Missouri pp. 171-194.

Collin, H. and Pareicia, N. L. (1970). Microbiology methods $3^{\text {rd }}$ Edition London University Press Butterworth.

Davies, J. (1994). Inactivation of antibiotics and the dissemination of resistant genes. Science 264, 375382.

De Silva, T. (2005) Industrial utilization of medicinal plants in developing countries. Industrial sector and Environmental Division UNIDO. pp. 1-11.

Desta, B. (1993). Ethiopia traditional herbal drugs part II antimicrobial activity of 63 medicinal plants. Journal of Ethnopharmacology 42, 129-139.

Erute, M. O. and Oyibo, A. E. (2008). Effects of three plants extract (Occimum gratissimum, Acalypha wilkesiana and Acalypha macrostachya) on post harvest pathogens of Persia Americana. Journal of Medicinal Plants Research 2, 311-314.

Evans, W. C. (2005). Trease and evans pharmacognosy. $15^{\text {th }}$ edn. Elsevier. pp. 20.

Kabir, O. A., Olukayode, O., Chidi, E. O., Christopher, C. I. and Kehinde, A. F. (2005). Screening of crude extracts of six medicinal plants used in South-west Nigerian orthodox medicine for anti methicillin resistant Staphylococcus aureus activity. BMC complementary and alternative medicine. [cited $10^{\text {th }}$ July 2009] http://www.biomedcentral.com/1472$6882 / 5 / 6$

Kloucek, P., Polesny, Z., Svobadova, B., Vloka, E. and Kokoska, L. (2005) Antibacterial sscreening of some Peruvian medicinal plants used in Calleria District. Journal of Ethnopharmacology 99, 309-312.

Liu, C. X. (1987). Development of Chinese medicine based on pharmacology and therapeutics. Journal of Ethnopharmacology 19, 119-123.

Nick, A., Rali, T. and Stitcher, O. (1995). Biological screening of traditional medicinal plants from Papua New Guinea. Journal of Ethnopharmacology 49, 147156.

Okwori, A. E., Dina, C. O., Junaid, S., Adetunji, J. A. and Olabode, A. O. (2007). Antibacterial activities of Ageratum conyzoides extracts on selected bacterial pathogens. The Internet Journal of Microbiology 4(1). [cited $3^{\text {rd }} \quad$ February 2008] http://www.ispub.com/journal/the_internet_journal_of microbiology/volume_4_number_1_26/article/antibact erial_activities_of_ageratum_conyzoides_extracts_on _selected_bacterial_pathogens.html 
Oladunmoye, M. K. (2006). Comparative evaluation of antimicrobial activities and phytochemical screening of two varieties of Acalypha wilkesiana. Trends in Applied Science Research 1, 538-541.

Rao, Y. R. and Rout, P. K. (2003). Geographical location and harvest time dependent variation in the composition of essential oils of Jasminum sambac. (L.) Aiton. Journal of Essential Oil Research, JEOR. Nov/Dec 2003. [cited 1st Sept 2009] http://findarticles.com/p/articles/mi_qa4091/is_200311 /ai_n9325900

Riley, $\bar{H}$. P. (1963). Families of plants of Southern Africa. University of Kenturkey press USA, pp. 73.

Sofowora, A. (1989). Traditional medicine and medicinal plants of Africa. Spectrum books Ltd. Ibadan, Nigeria. pp. 150-153.

Trease, G. E. and Evans, M. D. (1989). A Textbook of Pharmacognosy. Builler Tindall and Caussel London, $13^{\text {th }}$ edn. pp. $176-180$. 